ECONOMIC THEMES (2021) 59(2): 193-210

S sciendo

DOI 10.2478/ethemes-2021-0011

\title{
STRUCTURAL TRANSFORMATION OF THE TEXTILE INDUSTRY: THE CASE OF THE REPUBLIC OF SERBIA
}

\author{
Živorad Gligorijević
}

Faculty of Economics, University of Nis, Republic of Serbia

$\bowtie$ zivorad.gligorijevic@eknfak.ni.ac.rs

\section{Enes Ćorović}

State University of Novi Pazar, Republic of Serbia

$\bowtie$ enes.corovic@yahoo.com

\author{
Aleksandar Manasijević \\ PhD student, Faculty of Economics, University of Nis, Republic of Serbia \\ $\square$ aleksandar.manasijevic@eknfak.ni.ac.rs
}

UDC

$677(497.11)$

Review

paper

Received:

15.12.2020

Accepted:

28.02.2021

\begin{abstract}
In the last few decades, the textile industry has been marked by great changes in its production and trade structure. Based on that, a greater involvement of this industry in the flows of international trade was initiated, with the stable intensification of the export positions of new production leaders. At the same time, this has led to key changes in the regional allocation of exports and imports of textile products. On the other hand, the textile industry of the Republic of Serbia has a long tradition and has had an important place in the structure of manufacturing industry for a long time. After the Second World War, the textile industry was one of the most important instruments of demographic and social policy. During the construction of the market system, the textile industry of the Republic of Serbia was unjustifiably neglected. Despite that fact, in the modern conditions, the textile industry has very important place in the exports structure of the Republic of Serbia. This paper gives specific theoretical and empirical recommendations to Serbian policy creators, through a comparison of the results of structural transformation of the textile industry at the global level and the results of this process in the textile industry of the Republic of Serbia.
\end{abstract}

Keywords: textile industry, structural transformation, production, foreign trade, Republic of Serbia.

JEL classification: 014, L16, L52.. 


\section{Introduction}

The development of the textile industry in the last few decades, observed on a global scale, is a specific example of production in which major and, according to many, dramatic changes in the field of organization, production structure, technology and sales methods have taken place.

The textile industry has already exhausted its development potentials in developed countries (former leaders in the textile industry) from a typical laborintensive branch, with large investments and a simultaneous reduction in the number of employees, and has acquired a large number of characteristics of the capital-intensive branch.

The process of structural transformation of the textile industry of developed countries is accompanied by: the reduction of production volume and the number of employees, specialization and constant application of technological innovations, promotion and introduction of new products and production programs and so on.

Simultaneously, the process of moving production took place, and thus the creation of new world centers of the textile industry, whose key asset, besides low labor costs, was the availability of fairly large, affordable and cheap sources of raw materials.

This has led to a more intensive participation of the textile industry in global international trade, with obvious and constant intensification of the export positions of a group of certain developing countries, which has resulted in a main structural change in the regional distribution of textile production.

Having in mind the stated facts, the aim of this paper is to analyze and point out development trends, changes in the structure of production and foreign trade, as well as the key results of the process of structural transformation of the textile industry, both globally and at the level of the Republic of Serbia.

\section{Characteristics of the global structural transformation of the textile industry}

The phenomenology of the structural transformation of the textile industry on a global level is basically related to the existence and development of its two strategic development processes that took place simultaneously and with frequent intertwining. Having reached the stage of maturity, this industry had to secure its place among new, technologically and market-propulsive branches, whose emergence and intensive development in the early 1970s marked the process of structural transformation of developed economies, which are identified in the literature as reindustrialization. 
Faced with a tendency of constant decrease in demand, declining relative share of textile expenditures in the structure of household budget spending, slowing down the production growth and deteriorating relative price ratio to other products, the textile industry had to modernize: new (more modern) production programs, promotion and expanding the use of textiles in other industries and activities, innovative technological processes, more aggressive market performance and so on. These changes were supposed to stop and later (potentially) reverse the negative development trends in the textile industry.

The bearers of these changes were producers in developed countries, former leaders in the production and trade of textiles, since they were the first to feel the impact of these negative trends (Corovic et al., 2013). At the same time, the products of the textile industry of developing countries, especially from Asia, have appeared on the global textile market.

Due to considerably lower labor costs and domestic production of natural textile raw materials (especially cotton), this group of developing countries quickly changed the situation in international textile trade, in which, until then, developed, and mostly Western countries had a monopoly.

At that time, developed countries, although this was contrary to the neoliberal doctrine of development, were forced to apply certain protectionist measures of economic policy.

The protectionist measures by which developed countries have tried to protect their markets and producers have reduced the competitive pressure of developing countries and delayed their path to conquering a wider space in the international textile market. However, the continuity of these pressures has conditioned the beginning of the process of restructuring the textile industry of developed countries, in order for them to survive on domestic and international markets.

The directions of the process of restructuring the textile industry in developed countries have changed over the years. They initially led to the technological modernization of the mass production process and the application of the scientific research results in the field of the in the production of artificial and synthetic fibers and new technologies in spinning, weaving and textile finishing. Later, this concept was abandoned and replaced by one reflected in the relocation of production of standard, large-scale products to developing countries in the form of finishing jobs, the closure of unbeneficial production plants and the specialization of production.

With the development of the basic textile industry, that is, the production of yarns and fabrics in developing countries, finishing jobs have gradually given way to the import of finished products. With the abolition of the quota system in 2005, the largest world markets in Europe and the USA, in the segment of standard products, were definitely conquered by the producers from China, India, Turkey, Bangladesh, Pakistan and other Asian countries, whose products were of relatively acceptable quality and disproportionately lower prices. 
Gradually, the competitive struggle began to spread to the field of fashion products, which led to the latest phase in the process of structural transformation of the textile industry of developed countries, which gave the complete production of textiles a global character.

The process of reducing the relative share of the textile industry in the newly added value of the processing industry in the world can be traced back to the 1970 s, when the relative share of the textile production subsector (textile raw materials, yarns and fabrics) was $5 \%$ and the clothing subsector $3.9 \%$. In 1980 , there was a decrease in participation in these two subsectors to $4.1 \%$ and $5.5 \%$, respectively. The further decline continued, so that in 1990 the relative share of these subsectors of the textile industry was reduced to $3.4 \%$ and $3 \%$, respectively (UNIDO, 2010). After 2000, there was a rapid decline in the relative share of the textile industry in the newly added value of manufacturing, so in 2006 the textile production subsector had a relative share of only $1.9 \%$, and the clothing subsector of $1.3 \%$ (UNIDO, 2010).

The reason for this rapid decline in the relative share and, ultimately, the importance of the textile industry is contained in the relatively lower growth rates of production over the last for decades, compared to the very fast growth of propulsive branches.

Slightly more favorable flows, resulting from the relatively high growth of textile production in developing countries, were recorded in the period after the economic crisis in 2008, so in 2015 there was an increase in the relative share of these two subsectors of the textile industry to $2.4 \%$ and at $1.6 \%$ (UNIDO, 2018).

\section{Changes in the structure of textile production at the global level}

Unequal growth rates by individual subsectors of the textile industry in developed countries, developing countries and less developed countries, have led to major changes in the structure of textile production in the world. In addition, due to the unequal dynamics and directions of structural changes in national economies, there is a clear difference in the relative share of the textile industry in the newly added value of the manufacturing industry between developed and developing countries.

Namely, while, on the one hand, in the structure of the manufacturing industry in Great Britain, USA, Japan, Spain and other developed countries, textile production has a relative share of $1.2 \%$ to $1.8 \%$, and clothing production of $0.6 \%$ to $2.2 \%$, while on the other hand, in China, India, Turkey and other developing countries, with a dynamic and strong textile industry, this share in the first subsector ranges from $6 \%$ to $10 \%$, and in the second subsector from 3.5 to almost 8\% (UNIDO, 2010). 
The textile industry in the world, in an effort to maintain its position among new industries, has shown a high potential for applying new technologies, such as biotechnology and nanotechnology, but also for accepting innovations from other industries, especially chemical and mechanical, which resulted in diversification of production and increase of its competitiveness. These efforts have contributed to textile products from new production programs finding their application in other industries and activities, such as the automotive industry, the building materials industry, medicine, transport and so on.

In the sub-sector of clothing production, the most significant changes occurred in the structure of production, through the development of leisure clothing programs, jeans and sportswear. In an effort to stop the declining trend in consumption in this market segment, there has been a relative decline in production of the classic range, especially men's suits, women's suits women's dresses and men's coats and an increased production of individual garments, especially pants and jackets.

Competitive struggle on the market of textile products on a global level, in its modern phase has brought a number of innovations in production technology, its organization and sales logistics. The combined effects of this technological progress have enabled the spatial and functional fragmentation of textile production and its vertical disintegration, in terms of performing labor-intensive parts of the production process in countries with lower labor costs (Ćorović et al., 2020).

Functional fragmentation of the production process was made possible by liberalized channels of international trade, which led to the formation of supranational and global chains of production and trade. A cluster of most important transnational companies plays a major role in organizing and coordinating mentioned production systems (Ćorović, 2012).

In order to maintain and improve the competitiveness of leading firms, through strategic off-shoring and outsourcing, they relocate labor-intensive processes to developing countries, while retaining more complex jobs and capital-intensive processes in their countries. Thus, large retail chains and branded companies, which do not have their own production, have become dominant in determining what, how, how much and where to produce textiles, which has a decisive influence on structural changes in global production.

\section{Changes in the structure of foreign trade in textile products at the global level}

From the aspect of growth dynamics, foreign trade in textile products in the last two decades exceeds the growth of production in the world level. Exports and imports of both subsectors of the textile industry, after a period of stagnation from 1995 to 2000 , when the average growth rates of $0.6 \%$ and $1.4 \%$ were achieved, recorded a trend of accelerated increase, so that in 2005-2008 period, average growth rates of $7 \%$ and $6.6 \%$ were achieved (UNIDO, 2010). 
After a small decline in 2009 , the growth trend continued with better dynamics, with average growth rates of over $10 \%$ per year. The most significant participants in the global textile trade are: Asian developing countries, led by Peoples Republic of China, as well as the European Union.

The European Union ranked first among the textile exporters and until 2005 it was constantly increasing its relative share in world exports of textiles and clothing (in that year, that share was $32.1 \%$ ). Over the next six years, during which growth slowed down, its relative share in world exports declined to $26.4 \%$ in 2011, losing its leading position in this field.

The trend of declining relative share of this sector in world exports is recorded by the USA (since 2001) and other developed countries (in the period after the economic crisis in 2008). The Asian region, led by China and other developing countries, has recorded the highest export growth rates in this sector since the 1990s, and thus achieved a leading role in international trade as early as 2001 (Corovic et al., 2020).

Table 1: Trends in exports and imports of textiles and clothing (T\&C) at the world level, the most important regions and countries (in billions of dollars)

\begin{tabular}{|c|c|c|c|c|c|c|c|c|c|c|}
\hline $\begin{array}{l}\text { World / region } \\
\text { / country }\end{array}$ & 1990 & $\%$ & 2001 & $\%$ & 2005 & $\%$ & 2011 & $\%$ & 2018 & $\%$ \\
\hline \multicolumn{11}{|c|}{ Exports T\&C } \\
\hline THE WORLD & 212,5 & 100 & 355,0 & 100 & 481,4 & 100 & 770,6 & 100 & 799,1 & 100 \\
\hline $\begin{array}{l}\text { European } \\
\text { Union }\end{array}$ & - & - & 112,9 & 31,8 & 156 & 32,4 & 203,8 & 26,4 & 221,6 & 27,6 \\
\hline USA & 7,6 & 3,5 & 19,6 & 5,5 & 17,4 & 3,6 & 22,5 & 2,9 & 15,1 & 1,9 \\
\hline $\begin{array}{l}\text { Other } \\
\text { developed } \\
\text { countries }\end{array}$ & - & - & 20,4 & 5,7 & 27,8 & 5,7 & 30,8 & 3,9 & 25,56 & 3,2 \\
\hline $\begin{array}{l}\text { Asian } \\
\text { developing } \\
\text { countries }\end{array}$ & 76,6 & 36,0 & 145,9 & 41,1 & 225,6 & 46,8 & 448,3 & 58,2 & 537,7 & 67,3 \\
\hline China* & - & - & 50 & 14,1 & 110,3 & 22,9 & 245,1 & 31,8 & 289,2 & 36,2 \\
\hline \multicolumn{11}{|c|}{ Imports $\mathbf{T} \& \mathbf{C}$} \\
\hline THE WORLD & 220 & 100 & 376,4 & 100 & 508,4 & 100 & 719,1 & 100 & 746,0 & 100 \\
\hline $\begin{array}{l}\text { European } \\
\text { Union }\end{array}$ & - & - & 140,6 & 37,3 & 203,1 & 39,9 & 268,2 & 37,2 & 251,7 & 33,6 \\
\hline USA & 9,5 & 4,3 & 83,1 & 22,3 & 102,6 & 20,2 & 108,3 & 15,0 & 105,5 & 14,1 \\
\hline $\begin{array}{l}\text { Other developed } \\
\text { countries }\end{array}$ & - & - & 28,0 & 7,4 & 35,6 & 7,0 & 73,3 & 10,2 & 88,0 & 11,8 \\
\hline $\begin{array}{l}\text { Asian developing } \\
\text { countries }\end{array}$ & 41,8 & 19,0 & 50,0 & 13,3 & 59,7 & 11,7 & 171,4 & 23,8 & 302,1 & 40,5 \\
\hline China & - & - & 15,8 & 4,2 & 22,7 & 4,5 & 37,1 & 5,1 & - & - \\
\hline
\end{tabular}

* The calculation of exports and imports of textiles and clothing of the People's Republic of China entered the calculation of total exports and imports of textiles and clothing of Asian developing countries.

Source: Authors' calculation based on the International Trade Center database. Website: www.intracen.org. Site accessed: 25.04.2020. 
Based on data on textile and clothing exports (Table 1), a constant and a very rapid growth of the relative share of the Asian region can be observed. In that sense, the relative share of the Asian region in 2018 reached $67.3 \%$ of the world export of textiles and clothing. At the same time, in the period after 2008, China became the leading exporter of textile products at world level, whose relative share in total world exports in 2018 was $36.2 \%$.

Based on the presented facts, it can be concluded that developing countries from the territory of the Asian region in recent years have obviously taken the lead in the production and foreign trade of textiles and textile products.

When we talk about the import of textiles and clothes, the most important importer in the world is the European Union. At the same time, as a consequence of the economic crisis, a relative decline in imports in this market was recorded. However, in the last fifteen years, the USA has recorded a decline in the relative share in the world import of textiles and clothing.

On the other hand, in the period after 2008, a significant increase in the relative share in world imports of textiles and clothing was recorded by Asian developing countries. Mostly, it is about the increase in the volume of finishing works, on the basis of which the import of textile raw materials has increased.

\section{Structural transformation of the Serbian textile industry from 2000 to 2008}

The beginning of the $21^{\text {st }}$ century in the Republic of Serbia was marked by the normalization of its foreign policy position and return to the international trade system, on the one hand, as well as the beginning and realization of the entire process of structural transformation of the economy in the direction of building market relations. After a ten-year period of work and business in extremely unfavorable conditions during the last decade of the $20^{\text {th }}$ century, with extremely negative consequences for the entire economic structure of the country, there was a period of positive expectations in terms of creating conditions for accelerated economic growth and structural changes and increasing the efficiency of development of the entire national economy.

There was a widespread opinion that the process of structural transformation, and, especially, the process of privatization, will bring the necessary impetus for the financial and business consolidation of the failed social enterprises and that this is its primary goal. The process of macroeconomic stabilization should have served this purpose, creating a favorable business climate for the realization of other structural changes.

The country's opening to the world, after a period of war destruction during 1999 bombing, boosted production and exports. The war consequences of the decline in production, statistically speaking, were remedied at the end of 2001, 
which also applied to the textile industry. However, the commitment to shock therapy in the process of structural transformation, with the sudden liberalization of the foreign trade regime, very quickly achieved the opposite effects than expected.

Domestic industry, exhausted by a long period of recessionary flows and isolation, was not an equal competitor to more competitive bidders from developed and developing countries. With additional incentives for the overvalued value of the domestic currency, imports have become the dominant direction of foreign trade relations, in most sectors. The large presence of cheaper imported goods briefly relaxed the household budgets of the population, but it soon suffocated the domestic industry and stopped the process of its recovery. The basic assumption of the creators of economic policy, that the open market will accelerate the structural processes in the economy, was based on the wrong premise that this is an equal market competition and that it will contribute to increasing the competitiveness of domestic companies.

At the same time, the creators of economic policy did not have in mind the starting position of the industry of the Republic of Serbia, from which it started the process of stabilization, consolidation and structural transformation after 2000.

One of the first victims of the wrong and disastrous policy was the textile industry of the Republic of Serbia. The unprotected and unregulated domestic market of textile products has become an easy prey for highly competitive producers from the European Union, China and Turkey, as well as a hotbed of gray trade flows. After a short initial period of revival, the trend of declining production continued, with a slowdown in the positive structural changes in it. Production in originally private enterprises, to a large extent, remained in the gray zone, as an attempt to find an answer to the growing competitive pressure from imports.

On the other hand, the process of privatization of socially-owned enterprises did not bring the expected development impulse to this industry. With the load of accumulated financial problems and important redundancies, most big companies have bypassed the interest of private investors. The dominant concept of privatization, through the sale of capital, was the least tempting form of ownership restructuring of companies in the labor-intensive sector. The involvement of the state in the process of financial consolidation of large textile industry plants was slow and insufficient, with frequent attempts to privatize them as a whole. This wrong approach has led to delays and difficulties in finding strategic partners, which has resulted in a complete cessation of production in them. With the closure of key companies in the raw materials sector, there was a vertical disintegration of the textile industry of the Republic of Serbia, with long-term negative consequences for its unbiased development. Dependence of import has become main structural characteristic of this industry, regardless of the energetic growth of exports.

As it has already been pointed out, the textile industry of the Republic of Serbia has started to recover in the first years of normalization of the country's overall 
relations with the international environment. During 2000 and 2001, there was an increase in the physical volume of production in both sectors of this industry. The production of yarns and fabrics increased by about $10 \%$, while the production of underwear and clothing increased by about $40 \%$. Positive trends were also noted in the production of socks and floor coverings, which had the most favorable position in the previous period. Only the production of knitwear continued the downward trend. (Table 2) Due to the dynamic growth of production of socks and floor coverings, which according to the classification belong to the sector of yarns and fabrics, this part of the textile industry ended 2001 with a production volume of $30 \%$ of that achieved in 1990 .

The clothing production sector, due to the minimal statistical coverage of production in the private sector, at the same time, reached the level of $27 \%$ of the volume from the initial year of the observed period.

According to a free assessment, the production of clothing in micro enterprises and private entrepreneurs has already reached the volume of production in the social sector, which significantly changes the picture of relations in the textile industry.

Table 2: Trends in the production of certain products of the textile industry of the Republic of Serbia in the 2000-2008 period

\begin{tabular}{|c|c|c|c|c|c|c|c|c|c|}
\hline Year & $\begin{array}{c}\text { Cotton. } \\
\text { yarn } \\
\text { (tons) }\end{array}$ & $\begin{array}{c}\text { Woolen } \\
\text { yarn } \\
\text { (tons) }\end{array}$ & $\begin{array}{c}\text { Cotton } \\
\text { fabrics } \\
\left(000 \mathrm{~m}^{2}\right)\end{array}$ & $\begin{array}{c}\text { Woolen } \\
\text { fabrics } \\
\left(000 \mathrm{~m}^{2}\right)\end{array}$ & $\begin{array}{c}\text { Socks } \\
\text { (000 } \\
\text { of pairs) }\end{array}$ & $\begin{array}{c}\text { Floor } \\
\text { covers } \\
\left(000 \mathrm{~m}^{2}\right)\end{array}$ & $\begin{array}{c}\text { Laundry } \\
(000 \\
\left.\text { m }^{2}\right)\end{array}$ & $\begin{array}{c}\text { The } \\
\text { clothes } \\
000\left(\mathrm{~m}^{2}\right)\end{array}$ & $\begin{array}{r}\text { Tights } \\
\text { (tons) }\end{array}$ \\
\hline 2000 & 9234 & 7036 & 16000 & 5723 & 79642 & 5871 & 8947 & 18623 & 1633 \\
\hline 2001 & 9013 & 8028 & 15000 & 6382 & 141158 & 6727 & 10970 & 18000 & 811 \\
\hline 2002 & 6138 & 7383 & 9000 & 4617 & 141136 & 9905 & 5244 & 14873 & 931 \\
\hline 2003 & 1879 & 5728 & 14000 & 829 & 79732 & 5986 & 2154 & 5547 & 474 \\
\hline 2004 & 1048 & 762 & 18262 & 144 & 73505 & 7286 & 9463 & 3825 & 386 \\
\hline 2005 & 765 & 535 & 11765 & 103 & 76936 & 7086 & 1499 & 3450 & 219 \\
\hline 2006 & 600 & 477 & 16040 & 41 & 68984 & 8196 & 1372 & 3666 & 232 \\
\hline 2007 & 580 & 300 & 19557 & 11 & 101090 & 7422 & 7609 & 3035 & 331 \\
\hline 2008 & 1584 & 212 & 1701 & 2 & 101846 & 7228 & 7442 & 3086 & 289 \\
\hline
\end{tabular}

Source: Republic Statistical Office, Statistical Yearbook of Serbia 1996-2010.

Since 2002, a continuous decline in production in this industry has begun, which has led to its marginalization in the industrial structure of the Republic of Serbia. In contrast to the flows of total industrial production, which showed a tendency of slow recovery, in the next eight years, according to official statistics, the production of yarns and fabrics decreased at an average rate of $11.5 \%$, while the decline in clothing production was on average 19, 5\% per year. The largest decline in production was recorded in the 2002-2003 period, at the time of the most intensive privatization in the country. In those years, production in the yarn and fabric sector decreased by $13 \%$ and $28 \%$, respectively, while the decline in production in the clothing sector was by $33 \%$ and $41 \%$, respectively. 
One of the most important characteristics of the development of the private sector in this industry is contained in its business in the so-called gray zone. In order to avoid paying taxes and contributions to employees, minimal business changes were shown, which satisfied the legal form, which, to the greatest extent, distorts the statistical picture of the development flows of the textile industry as a whole.

After 2000, and especially since the beginning of the mass privatization of socially-owned enterprises, this phenomenon has spread even more dynamically and has partly spread to now private previously socially-owned enterprises from the textile industry. The statistical coverage of the realized production was mainly reduced to the results of the work of these companies, which over time became a smaller part of the total production.

This is clearly evidenced by the data on the growing import of basic raw materials for the clothing production sector, in which the most intensive positive structural changes took place with the emergence and development of private entrepreneurship. While the import of fabrics and knitwear shows a tendency of accelerated growth, at the same time, the data on the production of clothing and underwear indicate a drastic decline in production in this sector of the textile industry. In this way, a completely wrong picture of the structural changes in a large part of the textile industry in this period was obtained.

Table 3: Material balances of the clothing production sector and estimated unrecorded production volume in the $2000-2008$ period.

\begin{tabular}{|l|c|c|c|c|}
\hline \multicolumn{1}{|c|}{ Indicator } & $\mathbf{2 0 0 0}$ & $\mathbf{2 0 0 3}$ & $\mathbf{2 0 0 5}$ & $\mathbf{2 0 0 8}$ \\
\hline Annual fabric / ton production* & 7168 & 4893 & 4246 & 561 \\
\hline Annual import of fabrics / tons & 10976 & 13130 & 18103 & 21195 \\
\hline Annual export of fabrics / tons & 2310 & 1580 & 2243 & 2156 \\
\hline Annual production of knitwear / ton & 1633 & 474 & 219 & 289 \\
\hline Annual import of knitwear / ton & 4527 & 5965 & 5920 & 11782 \\
\hline Annual export of knitwear / ton & 257 & 51 & 174 & 227 \\
\hline $\begin{array}{l}\text { Annual input of fabrics and knitwear in the } \\
\text { manufacturing sector. clothes / tons** }\end{array}$ & 16302 & 17123 & 19553 & 23583 \\
\hline Annual production of the clothing / ton sector recorded & 9098 & 2541 & 1633 & 3474 \\
\hline $\begin{array}{l}\text { Estimated unrecorded annual production clothing sector } \\
\text { / ton }\end{array}$ & 7204 & 14582 & 17920 & 20109 \\
\hline Estimate\% of share of unrecorded in total production & 44 & 85 & 92 & 85 \\
\hline Estimation of clothing production index 1990=100 & 61 & 64 & 73 & 88 \\
\hline
\end{tabular}

* To recalculate the production of fabrics and the total production of the clothing sector from $000 \mathrm{~m} 2$ to tons, an assumption was taken about the average weight of fabrics of $330 \mathrm{~g} / \mathrm{m} 2$.

** The total available annual input of knitwear and fabrics in the clothing sector was reduced by $25 \%$ due to the share of pocket and lining fabrics, as well as decorative and technical fabrics, which are not included in the calculation of total production.

Source: Authors' calculation based on internal data of the Republic Statistical Office and data from the Statistical Yearbook of Serbia 1996-2010. 
In order to gain insight into the movement of the production volume of the clothing sector, in the absence of other indicators, the material balances of this part of the textile industry must be taken into account. A comparison of the available quantities of basic raw materials of this sector, during certain years, and the recorded volume of production, gives a rough picture of the volume of work on the "black". In the 2000-2008 period, the volume of clothing production recorded a continuous growth, due to the dynamic growth of imports of fabrics and knitted materials, primarily for finishing work. Compared with results from 2000 in 2008, the available input of raw materials in this sector increased by $57 \%$, which is completely contrary to the official statistics. A rough estimate of unrecorded production, accordingly, shows a dynamic growth since 2002, so that it is around $85 \%$ of total production. (Table 3 )

Liberalization of foreign trade flows and strengthening of competition on the market of textile products of the Republic of Serbia caused the abandonment of the imitative business strategy of domestic producers and the transition to an adaptive strategy. It was accompanied by a change in the marketing approach, which is dominated by the autonomous development of its own brands, with the expansion of brand shops and retail chains. However, the segment of the high purchasing power market is occupied by well-known world brands with their own sales, in all major city centers. Sales in multi-brand stores were also stagnant and slightly declining, while the sales of cheap imported goods, mainly from China and other countries in the region, in mega markets, were on the rise.

With the rapid liberalization of the foreign trade regime in the country, there has been a slowdown in positive structural processes in the clothing production sector. Under the burden of competition on the domestic market, production was increasingly focused on finishing jobs. Weak export incentives and financial uncertainty in conquering new markets have decisively influenced the choice of less risky options for filling capacity in the case of originally private companies.

Competitive pressures on the markets of the former Yugoslav republics also made it difficult to place finished products of Serbian brands, as the main source of profitable business. In order to preserve its market position, leading domestic producers have started to import less competitive products from their range, under their own brand, mainly from China. Not a small volume of these jobs additionally slowed down the processes of structural changes in the textile industry of the Republic of Serbia.

The most negative flows of structural changes are related to the raw materials sector of the textile industry of the Republic of Serbia. Slow and mismanaged privatization operations have led to the complete shutdown of the production of viscose fiber and artificial silk - raw materials of strategic importance for the entire textile industry. Paradoxically, the fact that the basic production in textiles, which had no competition on the domestic market, was physically destroyed due to the 
state's negligence and at the same time a secure export placement in the whole of Europe and the Far East. With a very small percentage of imported substance, these capacities had an extremely high multiplier effect on the production and export of the entire textile industry in the Republic of Serbia. The cessation of production of these textile raw materials caused the shutdown of the production of viscose yarns and their mixtures with other fibers, viscose fabrics, cord fabrics for the rubber industry, decorative fabrics for furniture, parts of the flooring industry and many other related products. The consequences were related not only to the need to import these products, but also to the impossibility to successfully privatize and deteriorate the complementary capacities of spinning mills, weaving mills, printing houses and dye houses, which were narrowly specialized in processing viscous raw materials.

Inadequate privatization of large textile factories, unsuccessful attempts to sell them as a whole, led to the complete marginalization of the production of cotton and woolen yarns and fabrics, as well as thread, and the country was left without the capacity for dyeing, printing and other finishing of raw fabrics. In that way, the raw material base of domestic producers of clothes, personal and household linen and other textile products was destroyed. In this way, the textile industry of the Republic of Serbia has lost the quality of a vertically integrated industry, with farreaching consequences for its import dependence.

With the shutdown of capacities in the field of basic textile industry, the accompanying production activities related to the production of utensils and spare parts also disappeared. A good part of the production of non-woven textiles and auxiliary materials for the production of clothing was left without raw materials, which determined the result of their privatization in advance. This sector has been reduced to the production of synthetic filaments and fabrics, socks, floor coverings, curtains, jams, embers and other products, which belong to its classification.

As a consequence of the economic crisis and the decline in the purchasing power of the domestic population, there was a significant decline in the production of finished textile products. The statistical growth of the production of clothing and underwear, which was recorded, is a consequence of the growth of finishing jobs, which is an indicator of the deterioration of the production structure on that basis. The growth of the production of socks continued with a marked dynamic, while the production of floor coverings decreased. However, despite the individual positive results, the textile industry had a decline in production during the crisis period, as did the entire industry.

\section{Structural transformation of the Serbian textile industry from 2009 to 2018}

The development of the textile industry of the Republic of Serbia, in the post crisis period, was conditioned by the effect of global economic processes that decisively influenced its development. The textile industry of the Republic of Serbia still has a 
unpretentious share in worldwide process of structural changes. This is, to a large extent, a consequence of its marginalization in the structure of the economy of the Republic of Serbia, which occurred during the transition process.

The relative share of textile and clothing production in the creation of newly added value of the processing industry of the Republic of Serbia is significantly lower, compared to countries with a similar level of development, which indicates structural deformations in its development. However, despite the negative production indicators in this period, this subsector of the economy of the Republic of Serbia retained the export potential, measured by the share of its exports in total exports of the country (Ćorović, 2010). There is a positive growth trend in its exports, which, for most of the last two decades, has been more dynamic in relation to trends in international trade.

In the period from 2010 to 2018 , the growth of textile industry production lagged behind the growth of the processing industry and the gross domestic product of the Republic of Serbia. Namely, while the manufacturing industry grew at an average annual rate of $2.2 \%$, and gross domestic product at an average annual rate of $1.02 \%$, the production of subsector 13 - textile production recorded a negative average growth rate of $-1.13 \%$ per year, and the production of subsector 14 clothing production had an average annual growth of $1.1 \%$ (Statistical Yearbook of the Republic of Serbia, 2016, 2019).

It is obvious that the slight growth of the relative share of the processing industry in the creation of the gross domestic product of the Republic of Serbia was not complementary to the growth dynamics of the textile and clothing production subsector. This situation is very much a result of the insufficient volume of investments, which is current in both the textile and processing industries.

Namely, the increase in the volume of investments in the real sector is the first condition for eliminating the basic imbalance in the structure of the formation of the gross domestic product of the Republic of Serbia - low relative share of the real sector. Without entering the analysis of the causes of this situation on this occasion, it should be pointed out that investments in the textile industry make up $0.64 \%$ of the total investments in 2018, which is approximately the relative share of this industry in creating gross domestic product.

In the field of foreign trade relations, this subsector of the economy of the Republic of Serbia has maintained a very positive growth trend of its real share in the structure of total national exports. At the same time, as we have already mentioned, the growth of the relative share of textile and clothing production in the structure of total national exports in the last fifteen years is more dynamic in relation to the trends in international trade in textiles and textile products.

In the 2009-2018 period, the export of the Serbian textile industry to the European Union market significantly increased from 392 million euros to 911 
million euros. In that same period, the world exports of textile products increased by $22 \%$, and exports of these products from around the world to the European Union market by $24 \%$.

At the same time, exports of subsector 13 in Republic of Serbia recorded higher growth dynamics compared to subsector 14, both on the European Union and world market. Cumulatively, the exports of subsector 13 to the European Union market increased by $373 \%$ and to the world market by $178 \%$, while the growth of subsector 14 was at the level of $27.7 \%$ and $60.5 \%$, respectively (Authors' calculation based on the International Trade Center database. Website: www.intracen.org. Site accessed: 27.04.2020).

Table 4: Exports of certain branches of the manufacturing industry of the Republic of Serbia to the European Union market in the 2009-2018 period (millions of EUR)

\begin{tabular}{|c|c|c|c|c|c|c|c|}
\hline $\begin{array}{l}\text { Products } \\
\end{array}$ & 2009 & 2010 & 2012 & 2013 & 2014 & 2016 & 2018 \\
\hline $\begin{array}{l}\text { Manufacture of food products and } \\
\text { beverages }\end{array}$ & 504 & 531 & 616 & 693 & 691 & 935 & 897 \\
\hline Manufacture of tobacco products & & 1 & 2 & 2 & 2 & 1 & 13 \\
\hline Textile production & 31 & 38 & 65 & 80 & 114 & 144 & 194 \\
\hline $\begin{array}{l}\text { Production of clothing and leather } \\
\text { items }\end{array}$ & 361 & 392 & 435 & 448 & 524 & 626 & 717 \\
\hline $\begin{array}{l}\text { Wood processing and wooden } \\
\text { products, except furniture. }\end{array}$ & 56 & 66 & 87 & 105 & 111 & 121 & 143 \\
\hline $\begin{array}{l}\text { Manufacture of paper and paper } \\
\text { products }\end{array}$ & 62 & 82 & 107 & 128 & 183 & 215 & 257 \\
\hline $\begin{array}{l}\text { Printing and duplicating. audio and } \\
\text { video recordings }\end{array}$ & 19 & 19 & 26 & 31 & 30 & 36 & 43 \\
\hline $\begin{array}{l}\text { Manufacture of coke and refined } \\
\text { petroleum products }\end{array}$ & 83 & 162 & 134 & 245 & 241 & 198 & 418 \\
\hline $\begin{array}{l}\text { Manufacture of chemicals and } \\
\text { pharmaceutical products }\end{array}$ & 162 & 312 & 238 & 408 & 403 & 572 & 255 \\
\hline $\begin{array}{l}\text { Manufacture of rubber and plastic } \\
\text { products }\end{array}$ & 246 & 295 & 414 & 509 & 757 & 914 & 1139 \\
\hline $\begin{array}{l}\text { Product. non-metallic mineral } \\
\text { products }\end{array}$ & 34 & 35 & 47 & 44 & 55 & 77 & 123 \\
\hline Production of base metals & 614 & 929 & 618 & 561 & 673 & 760 & 1434 \\
\hline $\begin{array}{l}\text { Product. metal products, except } \\
\text { machinery }\end{array}$ & 135 & 153 & 284 & 280 & 269 & 271 & 310 \\
\hline $\begin{array}{l}\text { Manufacture of computers, electrical } \\
\text { and optical equipment }\end{array}$ & 102 & 82 & 155 & 162 & 79 & 92 & 110 \\
\hline Manufacture of electrical equipment & 351 & 534 & 548 & 652 & 795 & 1247 & 1480 \\
\hline $\begin{array}{l}\text { Engine production vehicles and other } \\
\text { transport assets }\end{array}$ & 282 & 308 & 723 & 1690 & 1744 & 1933 & 2171 \\
\hline Furniture production & 56 & 71 & 97 & 126 & 179 & 327 & 767 \\
\hline In total & 3101 & 4010 & 4596 & 6163 & 6850 & 8470 & 10920 \\
\hline
\end{tabular}

Source: www.intracen.org: Trade statistics - International trade center. Site accessed: 25.01.2020. 
Observed from the aspect of the processing industry, the textile industry of the Republic of Serbia takes up the fifth place, in terms of the volume of exports to the European Union market in 2018, after the export of motor vehicles, electrical equipment, rubber and plastic products and electrical equipment. The second indicator, which marks a relatively large potential of the textile industry, is the result of a comparative analysis of the market share of certain industries of the processing industry of the Republic of Serbia. Although this is a relatively marginal market share resulting from low levels of production, it can be seen that the textile industry is recording a continuous growth of market share and that, in terms of market share in 2018, it ranks fifth, behind the food industry, paper production, chemical industry and furniture manufacturing.

Table 5: Market share of individual branches of the manufacturing industry of the Republic of Serbia on the European Union market in the 2009-2018 period (in \%)

\begin{tabular}{|l|c|c|c|c|c|c|c|}
\hline \multicolumn{1}{|c|}{ Products } & $\mathbf{2 0 0 9}$ & $\mathbf{2 0 1 0}$ & $\mathbf{2 0 1 2}$ & $\mathbf{2 0 1 3}$ & $\mathbf{2 0 1 4}$ & $\mathbf{2 0 1 6}$ & $\mathbf{2 0 1 8}$ \\
\hline $\begin{array}{l}\text { Manufacture of food products and } \\
\text { beverages }\end{array}$ & 0.168 & 0.164 & 0.162 & 0.190 & 0.187 & 0.209 & 0.225 \\
\hline Manufacture of tobacco products & 0.028 & 0.008 & 0.020 & 0.015 & 0.020 & 0.020 & 0.009 \\
\hline Textile production & $\mathbf{0 . 0 5 5}$ & $\mathbf{0 . 0 5 9}$ & $\mathbf{0 . 0 9 6}$ & $\mathbf{0 . 1 1 5}$ & $\mathbf{0 . 1 4 6}$ & $\mathbf{0 . 1 5 5}$ & $\mathbf{0 . 1 7 2}$ \\
\hline $\begin{array}{l}\text { Production of clothing and leather } \\
\text { items }\end{array}$ & $\mathbf{0 . 2 3 9}$ & $\mathbf{0 . 2 3 1}$ & $\mathbf{0 . 2 3 7}$ & $\mathbf{0 . 2 4 3}$ & $\mathbf{0 . 2 4 7}$ & $\mathbf{0 . 2 3 6}$ & $\mathbf{0 . 2 6 7}$ \\
\hline $\begin{array}{l}\text { Wood processing and wooden } \\
\text { products except furniture }\end{array}$ & 0.180 & 0.183 & 0.237 & 0.278 & 0.321 & 0.303 & 0.273 \\
\hline $\begin{array}{l}\text { Manufacture of paper and paper } \\
\text { products }\end{array}$ & 0.098 & 0.112 & 0.142 & 0.199 & 0.237 & 0.267 & 0.283 \\
\hline $\begin{array}{l}\text { Printing and duplicating. audio } \\
\text { and video recordings }\end{array}$ & 0.066 & 0.064 & 0.092 & 0.114 & 0.108 & 0.131 & 0.118 \\
\hline $\begin{array}{l}\text { Manufacture of coke and refined } \\
\text { petroleum products }\end{array}$ & 0.020 & 0.030 & 0.017 & 0.033 & 0.037 & 0.039 & 0.048 \\
\hline $\begin{array}{l}\text { Manufacture of chemicals and } \\
\text { pharmaceutical products }\end{array}$ & 0.035 & 0.063 & 0.040 & 0.069 & 0.066 & 0.071 & 0.089 \\
\hline $\begin{array}{l}\text { Manufacture of rubber and plastic } \\
\text { products }\end{array}$ & 0.274 & 0.338 & 0.343 & 0.378 & 0.282 & 0.284 & 0.321 \\
\hline $\begin{array}{l}\text { Product. non-metallic mineral } \\
\text { products }\end{array}$ & 0.079 & 0.073 & 0.091 & 0.085 & 0.100 & 0.101 & 0.124 \\
\hline Production of base metals & 0.354 & 0.385 & 0.190 & 0.203 & 0.223 & 0.257 & 0.217 \\
\hline $\begin{array}{l}\text { Production metal products, except } \\
\text { machinery }\end{array}$ & 0.149 & 0.136 & 0.234 & 0.225 & 0.304 & 0.278 & 0.294 \\
\hline $\begin{array}{l}\text { Production of computers, } \\
\text { electrical and optical instruments }\end{array}$ & 0.033 & 0.022 & 0.042 & 0.043 & 0.031 & 0.030 & 0.021 \\
\hline Manuf. electrical equipment & 0.089 & 0.114 & 0.112 & 0.125 & 0.146 & 0.159 & 0.189 \\
\hline $\begin{array}{l}\text { Engine production vehicles and } \\
\text { other transport assets }\end{array}$ & 0.069 & 0.066 & 0.145 & 0.327 & 0.316 & 0.280 & 0.277 \\
\hline Furniture production & 0.117 & 0.133 & 0.172 & 0.219 & 0.287 & 0.381 & 0.432 \\
\hline In total & 0.101 & 0.111 & 0.110 & 0.148 & 0.163 & 0.170 & 0.184 \\
\hline
\end{tabular}

Source: Authors' calculation based on data from: site www.intracen.org: Trade statistics International trade center. Site accessed: 29.1.2020. 
Based on the previous analysis, it is possible to state diametrically different results of the growth of the volume of production and the volume of exports of the textile industry of the Republic of Serbia. These seemingly contradictory trends stem from the fact that the exports of the Republic of Serbia are still based on low and medium low technology products (Ćorović, Gligorijević \& Manasijević, 2019).

\section{Conclusion}

Current changes in the world market of textile products indicate the growing role of the textile industry in developing countries (mainly from the territory of the Asian region) both in production and in international trade. Thanks to the high dynamics of export growth of these countries, in the last twenty years, the international trade of textiles and clothing has significantly increased its volume and in all segments exceeded the growth of production in the world.

At the same time, there have been radical changes in the vertical and horizontal structure of the world market of textiles and textile products, as well as the order of key participants in it. Numerous empirical studies in the world have found a high degree of correlation between the rate of economic growth of developing countries, on the one hand, and the growth of exports and competitiveness of their textile industry, on the other.

The last few decades in the development of the textile industry, at the global level, have been characterized by very dynamic and intensive processes of structural transformation, which have resulted in the specific shift of the focus of production from developed countries to developing countries. This resulted in a greater participation of this industry in global international trade flows, with the stable intensification of export positions of new production leaders. Such flows at the international level have led to large and specific changes in the regional allocation of exports and imports of textile products.

As for the textile industry of the Republic of Serbia, despite insufficient investments, it is one of the key branches of the manufacturing industry, both in terms of relative share in the structure of total national exports, percentage of absolute and relative market share (ranked fifth) and relative share in the structure of total employment and national gross domestic product.

\section{References}

Aranđelović, Z., \& Gligorijević, Ž. (2008): Nacionalna ekonomija, Niš: Petrograf.

Corovic, E., Jovanovic, P. \& Ristic, L. (2013): Current Trends on the World Textile Market and the Competitiveness of the Serbian Textile Industry, Lodz, Fibres \& Textiles in Eastern Europe, 5(101). 
Čukul, D. (2008): Competitive aspects of Turkish and Chinese textile and clothing industries, 8th Global Conference of Business and Economics, Florence, Italy.

Ćorović, E. (2010): Tekstilna industrija Srbije u procesu liberalizacije trgovinskih odnosa, Ekonomika broj 2, Niš.

Ćorović, E. (2012): Efekti privatizacije tekstilne industrije Srbije, Ekonomika broj 3, Niš.

Ćorović, E. (2012): Uloga tekstilne industrije u procesu strukturnog prilagođavanja privrede Srbije, PhD thesis, Ekonomski fakultet u Nišu.

Ćorović, E., Gligorijević, Z., \& Kostadinović, I. (2020): Export competitiveness of textile and clothes of Western Balkan countries, FIBRES \& TEXTILES in Eastern Europe, 28, 4(142).

Ćorović, E., Gligorijević, Ž., \& Manasijević, A. (2019): Revealed comparative advantages and competitiveness of the manufacturing Industry of the Republic of Serbia, Economic themes 57(3), Niš: Ekonomski fakultet.

Gereffi, G., \& Memedovic, O. (2003): The global apparel value chain: what prospects for upgrading for developing countries, Sectoral Studies Series. Vienna, Austria: United Nations Industrial Development Organization (UNIDO).

Gligorijević, Ž., (2019): Ekonomika industrije, Niš: SVEN.

Gligorijević, Ž. \& Ćorović, E. (2019): Strukturne promene i novi model rasta Republike Srbije, Niš: Ekonomski fakultet.

Gligorijević, Ž., \& Bošković, G. (2007): Mehanizam unapređenja konkurentnosti industrije, Niš: Ekonomski fakultet.

Gligorijević, Ž., \& Ćorović, E. (2018): Ekonomika industrije, Novi Pazar: Državni Univerzitet u Novom Pazaru.

Gligorijević, Ž., \& Ćorović, E. (2020): Competitiveness of the textile industry of the Republic of Serbia, Economic themes 58(1): 1-16.

Gligorijević, Ž., Ćorović, E., \& Manasijević, A. (2020): Strategijski pravci održivog razvoja tekstilne industrije Republike Srbije, Digital economy: chances, risks, sustainable development, International Scientific Conference, Niš: Faculty of Economics.

International trade center (2020) Trade statistics, available at: www.intracen.org.

Kovačević, M. (2010): Uzroci pada i vrlo niskog nivoa konkurentnosti privrede Srbije, Kako povećati konkurentnost privrede i izvoza Srbije, Beograd: Naučno društvo ekonomista Srbije.

Raičević, V., \& Ćorović, E. (2010): Liberalizacija trgovine sa Turskom i njen uticaj na tekstilnu industriju Srbije. Pravo - teorija i praksa 7-8, Novi Sad.

Raičević, V., \& Ćorović, E. (2010): Spoljno-trgovinska razmena tekstilne industrije Srbije Stanje i pravci promena. Pravo - teorija i praksa broj 7-8, Novi Sad.

Republički zavod za statistiku (2016, 2019): Statistički godišnjak.

Savić, Lj. (2009): Ekonomika industrije, Beograd: Ekonomski fakultet.

UNIDO (2010): Structural Change in the World Economy: Main Features and Trends, Vienna.

UNIDO (2010): The Impact of Institutions on Structural Change in Maufacturing: The Case of International Trade Regime in Textiles and Clothing, Working Paper 25/2009, Vienna.

UNIDO (2018): Industrial Development Report 2018, Vienna.

Urošević, S. (2009): Kvalitet - preduslov ostvarivanja prosperiteta i konkurentnosti tekstilne industrije, International Journal Total Quality Menagement \& Excellence, Vol. 37, No $1-2$. 


\title{
STRUKTURNA TRANSFORMACIJA TEKSTILNE INDUSTRIJE: SLUČAJ REPUBLIKE SRBIJE
}

\begin{abstract}
Abstrakt: U poslednjih nekoliko decenija, tekstilna industrija karakteriše se velikim promenama u proizvodnoj i trgovinskoj strukturi. $\mathrm{Na}$ osnovu toga, inicirano je veće uključivanje ove industrijske grane $u$ tokove međunarodne trgovine, uz stalno jačanje izvoznih pozicija novih proizvodnih lidera. To je, istovremeno, dovelo do velikih promena u regionalnoj distribuciji izvoza i uvoza tekstilnih proizvoda. Na drugoj strani, tekstilna industrija Republike Srbije ima dugu tradiciju i veoma važno mesto u strukturi prerađivačke industrije. Posle Drugog svetskog rata, tekstilna industrija bila je jedan od najvažnijih instrumenata demografske i socijalne politike. Tokom izgradnje tržišnog sistema, tekstilna industrija Republike Srbije bila je neopravdano zapostavljena. Uprkos tome, u savremenim uslovima, tekstilna industrija ima veoma važno mesto $u$ strukturi izvoza Republike Srbije. Ovaj rad daje konkretne teorijske i empirijske preporuke kreatorima politika u Srbiji, upoređivanjem rezultata strukturne transformacije tekstilne industrije na globalnom nivou i rezultata ovog procesa $\mathrm{u}$ tekstilnoj industriji Republike Srbije.
\end{abstract}

Ključne reči: Tekstilna industrija, strukturna transformacija, proizvodnja, spoljna trgovina, Republika Srbija.

\section{Authors' biographies}

Živorad Gligorijević, $\mathbf{P h D}$ was born in 1954. He obtained his bachelor's degree at the Faculty of Economics in Niš and completed his postgraduate studies at the Faculty of Economics in Belgrade. He defended his PhD dissertation at the Faculty of Economics in Niš. Since June 1st, 1980 he has been working at the Faculty of Economics in Niš. He teaches Economics of industry, Industrial management and Economics of tourism at undergraduate studies level, Regional economics at master studies level and Industrial economics at $\mathrm{PhD}$ studies level. $\mathrm{He}$ is the author of a numerous scientific papers, monographs and textbooks of both national and international significance.

Enes Ćorović, PhD, was born in 1957. He completed his undergraduate and postgraduate studies at the Faculty of Economics in Belgrade. He defended his $\mathrm{PhD}$ dissertation at the Faculty of Economics in Niš. From 2010, until he was elected an Assistant Professor in 2016, he worked at the following positions: Associate at the Research centre, Teaching Associate and Teaching Assistant with a $\mathrm{PhD}$. He published several scientific papers, textbooks and monographs.

Aleksandar Manasijević, MSc, was born in 1997. He obtained both his bachelor and master degree at the Faculty of Economics in Niš. Currently he is a PhD student at same faculty. He has participated in numerous projects of national and international importance. He is the founder and the head of the Student science and Research centre at the Faculty of Economics in Nišs, and the editor-in-chief of the collection of students' papers "Regional development and demographic flows". So far, he has published more than 20 scientific papers and one monograph. 